\title{
The importance of LNG for natural gas consumption in the EU
}

\author{
Klaudia Metelska1, Rafał Biały², Tomasz Cieślik1,3, Tomasz Blacharski and Adam Szurlej, ${ }^{1, a}$ \\ ${ }^{1}$ AGH University of Science and Technology, Faculty of Drilling, Oil and Gas \\ ${ }^{2}$ AGH University of Science and Technology, Faculty of Energy and Fuels \\ ${ }^{3}$ Polish Academy of Science, Institute of Nuclear Physics, Aleja Radzikowskiego 152, 31-342 Kraków \\ ${ }^{4}$ Polska Spółka Gazownictwa sp. z o.o. (Polish Gas Company), ul. Marcina Kasprzaka 25, 01-224 Warszawa
}

\begin{abstract}
The World market of liquefied natural gas (LNG) is growing rapidly. In 2015 LNG production exceeded 333 bcm with its predicted increase up to $450 \mathrm{bcm}$ in 2019. The analysis of LNG role in natural gas import to the EU in recent years shows variability: LNG share in overall import reached $25 \%$ in 2011 and it went down to $15 \%$ in 2014 . The smaller demand for natural gas including LNG in the EU can be due to, among others, a slower economic growth and a dynamic development of the use of renewable energy sources. The article shows the role of natural gas in the structure of consumption of primary energy as well as the changes in demand for natural gas in the years 2007-2014 for the main groups of end users: industry, energy production and individual households. The biggest fall in demand for natural gas has been observed in energy production sector in recent years. This publication continues to analyse the structure of natural gas supplies to the EU, with special emphasis on the directions of LNG import to the countries such as: The UK, Spain, France, Greece, Belgium, Portugal, Italy, Lithuania and The Netherlands. The significance of LNG in the balance of consumption of natural gas in these countries has been presented as well as the infrastructure connected with LNG and plans of development of regasification terminals. In the summary the most important conclusions have been drawn and a chance of the increase in significance of the role of LNG in the balance of natural gas supplies has been pointed out, which is due to the steep fall of $\mathrm{LNG}$ prices which has taken place in recent years.
\end{abstract}

\section{Introduction}

The main alternative for gas supplies through the gas pipeline network is its import in the form of liquefied natural gas (LNG) by sea in order to balance the demand for natural gas in the selected UE countries. The analysis of the significance of LNG in satisfying the demand for gas shows that it has changed rapidly all over the world in recent years. In so far as in 2007 the world production of LNG amounted to $230 \mathrm{bcm}$, it exceeded $333 \mathrm{bcm}$ in 2015 with its predicted growth to at least 450 bcm by the end of 2019 [1]. In the years 2001-2014 the volume of natural gas trade in the liquefied form rose annually by $9.5 \%$ which is more than twice as much $(4.5 \%)$ compared to the gas sent by pipeline networks. It needs to be stressed that the regasification capabilities exceed significantly liquefying capabilities (in 2001 the ratio of regasification capabilities to liquefying capabilities was 2.14 and in $2013-2.46$ ). The increase in significance of LNG is connected, above all, with the increase in demand for natural gas as well as the high level of irregularity of the location of natural gas deposits which results in the need for LNG long distance transport - the average distance in 2015 was $14260 \mathrm{~km}$ (16 days). LNG is a form of condensed ecological energy and thanks to its properties it can be transported on long distances. One thing which is important is that this energy carrier is commonly accepted [2]. It is confirmed

\footnotetext{
a Corresponding author: szua@agh.edu.pl
}

by the strategy proposed by the European Commission and accepted by The Council of Europe in March 2015 for stable energy union, which assumes strengthening the role of LNG on the European market of natural gas. The new EU energy policy aims at providing its consumers with safe, balanced and competitive energy at affordable prices. LNG plays an important role in this policy, especially in guaranteeing the security of supplies as well as raising the integration and competitiveness of the gas market [3]. As far as energy security is concerned, diversification of supplies of natural gas is to be based on creating in northern and central Europe LNG trade centres which will guarantee diversification of suppliers. These centres are supposed to ensure the possibility of buying gas from suppliers all over the world. The strategy of action which bases on the full use of the potential of access to the international LNG market falls within three areas [4]: infrastructure, which gives access to LNG directly or through other member states, completing the construction of the internal gas market which sends the right price alerts and the necessity of removing barriers in LNG trade and the promotion of the free market. The existing EU LNG terminals have sufficient regasification capabilities to satisfy the needs but they are not fully used (in 2013 the scale of use of terminals worldwide was around $35 \%$ while the EU figure was around 20\%) [5]. 


\section{The volume of consumption of natural gas in the years 2007-2014 and its structure of use}

In 2004 in the EU primary gas consumption amounted to 213 thousand TWh, coming both from fossil fuels and renewable sources of energy while in 2014 energy consumption decreased to 211 thousand TWh. The drop in energy consumption is due to the economic slump in the years 2008/2009 whose effects are still visible in many EU countries and are characterised by low indexes of GDP growth. The declining trend regarding energy consumption is also connected with the introduction of the suitable regulations by the European Parliament in 2009 (so called climate and energy package) which assume a $20 \%$ reduction of greenhouse gases by 2020 (compared to the level in 1990), a $20 \%$ share of renewable sources of energy in the total energy consumption in the EU and a $20 \%$ increase in the energetic effectiveness [6][7]. A significant growth of the amount of renewable energy being used can be observed which is accompanied by the decrease in the use of fossil fuels which should be treated as the realisation of the adopted commitments of the EU member states. In 2004 the share of natural gas was $24 \%$ in the structure of primary energy consumption and in 2014 its share declined to $21 \%$. For the sake of comparison the share of renewable energy rose from $6 \%$ in 2004 to $13 \%$ in 2014 . Analysing natural gas consumption in the $\mathrm{EU}$ in absolute terms, in the years 2005, 2008 and 2010 it was at its highest at $500 \mathrm{bcm}$. To illustrate the volume of the decline of natural gas consumption, the consumption of natural gas in 2014 can be shown - $387 \mathrm{bcm}[8][9]$.

In the EU natural gas is used in three main sectors: individual households, industry and energy production. A fall in gas consumption in the energy production sector can be observed (fig.1). It was caused, among other things, by the continuing relatively high prices of gas on the European market and by the appearance of cheap coal from The United States on the European market and by the focus of the majority of countries on the development of renewable energy use. [10]. In 2007 gas consumption by individual households was $34 \%$ with $33 \%$ in the industry and $26 \%$ in the energy production sector. In 2014 an increase in gas consumption by individual households to the level of $41 \%$ took place while in the industry it stayed on the same level and gas consumption in the energy production sector decreased to $23 \%$ [8]. In 2007 individual households gas consumption was $164 \mathrm{bcm}$. In Poland it was $5.13 \mathrm{bcm}$. In 2014 a fall in the consumption of gas by individual households took place to the level of $158 \mathrm{bcm}$ whereas in Poland it rose to $5.40 \mathrm{bcm}$. It is worth mentioning that countries such as Germany, France, Italy, the UK, Spain and the Netherlands had a $82 \%$ share in the gas consumption by individual households in 2007. In 2014 this share was $80 \%$ which means that an increase in individual households gas consumption in countries such as Poland, Belgium, Romania and Portugal [8].

In 2007 gas consumption by the industry in the EU was $156 \mathrm{bcm}$. In Poland the consumption was $7.1 \mathrm{bcm}$.
In 2009 a significant decrease in gas consumption to the level of 137 billion cubic metres took place, mainly because of the economic crisis. In 2011 while a fall in two other sectors was observed, namely, the energy production sector and individual households, an increase in the industry to the level of $149 \mathrm{bcm}$ could be seen. In 2014 the EU industry gas consumption decreased to $128 \mathrm{bcm}$ but in Poland it rose to $7.74 \mathrm{bcm}$. It needs to be observed that $72 \%$ of gas consumed by the industry in 2007 was in Germany, France, Italy, the UK, Spain and the Netherlands. In 2014 it was $71 \%$ which means a minimal increase in gas consumption by the industry in countries such as Poland, Finland and Estonia [8].

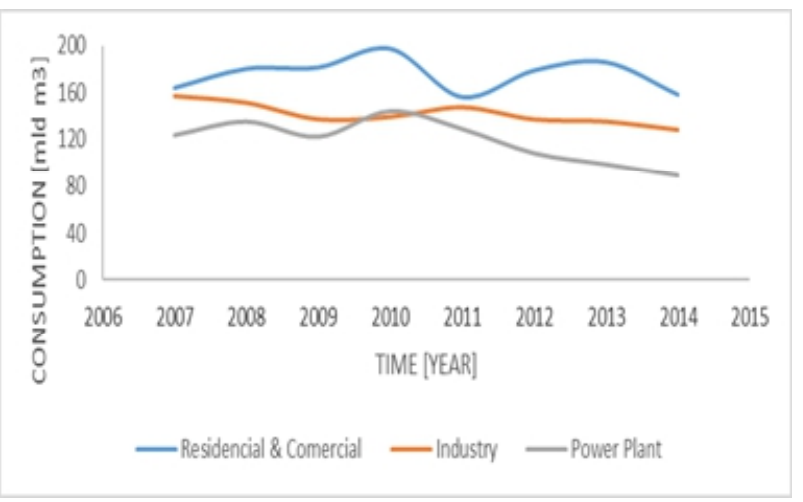

Figure 1. Gas consumption in different sectors (own study based on the data [8]).

In 2007 the EU gas consumption in the energy production sector was 124 billion cubic metres. In Poland it was $0.9 \mathrm{bcm}$. In 2014 a significant fall in consumption in energy production in the EU took place to the level of $88 \mathrm{bcm}$. In Poland, however, it rose to $1.35 \mathrm{bcm}$. It has to be said that $78 \%$ of gas consumed by the energy production sector was in countries such as Germany, France, Italy, the UK, Spain and the Netherlands but in 2014 it reached the level of 76\%. In 2014 an increase in gas consumption in the energy production sector could be observed merely in countries such as Poland, France and Estonia [8]. However, as can be clearly seen, in recent years the biggest decrease in natural gas consumption was recorded in the energy production sector - in the years 2010 - 2014 it dropped by almost $40 \%$.

\section{The structure of gas supplies to the EU}

In $2007304 \mathrm{bcm}$ of natural gas were imported to balance the supplies while the extraction was $187 \mathrm{bcm}$. In 2014 due to a smaller demand for natural gas, its import fell to $270 \mathrm{bcm}$ and the extraction to $141 \mathrm{bcm}$. Countries such as Germany, France, Italy, the UK, Spain and the Netherlands extracted $85 \%$ of gas in the EU in 2007 but in $2014-79 \%$. The analysis of the recent years indicates a declining trend of receiving gas from deposits in the EU, which is confirmed by a twofold decrease in the extraction of gas in the UK in the years 2007-2014 (37 billion cubic metres in 2014) [8][9]. Recent attempts to make use of unconventional natural gas deposits have been unsuccessful. Poland and Great Britain are the 
countries which have made the biggest effort in looking for these deposits [11].

At present natural gas is imported to the EU from Norway, Russia, Africa and The Middle East. The European Union has LNG terminals located in Great Britain, Poland, Spain, France, Greece, Belgium, Portugal, Italy, Lithuania and the Netherlands. It needs to be emphasized that $100 \%$ of supplies came from Russia in countries such as Estonia, Finland and Latvia. However, Bulgaria, Austria, Hungary, Slovakia, Slovenia and Poland received gas to satisfy from $89 \%$ to $59 \%$ of the demand (fig. 2) [8]. Therefore the Russian Ukrainian gas crisis of early 2009 spread on many Central Europe countries [12].

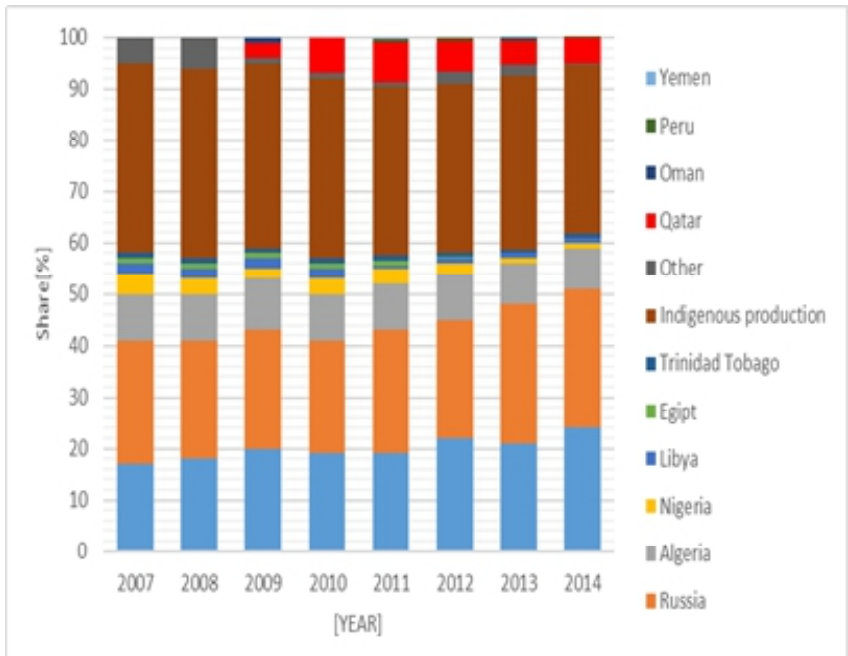

Figure 2. The structure of natural gas import to the EU (own study based on [8])

\section{LNG share in balancing natural gas consumption in the European Union}

LNG import to the EU countries possessing regasification terminals (with the re-export correction) in normal conditions was ca. $53 \mathrm{bcm}$, which covered $11.9 \%$ of the total demand for natural gas in the EU. In 2013 economic slump and the increase in the use of coal in the EU industry caused a reduction of import of LNG to $37.44 \mathrm{bcm}(8.6 \%$ of the total demand for natural gas in the EU). In 2014 a further decline in the import of LNG was recorded to the level of $34.27 \mathrm{bcm}$, which resulted in the reduction of the share of gas imported to Europe in the world import of LNG to $13.9 \%$ (footnote - including Turkey). An increase was observed in 2015 when over $40 \mathrm{bcm}$ of gas were imported to the EU. Attention should be drawn to the fact that in this period gas in the amount of $4.65 \mathrm{bcm}$ was exported from the EU (mainly from Spain, the Netherlands and Belgium). The table 1 and fig. 3 show selected data with functioning LNG terminals in the EU countries as well as the directions of supplies of LNG. In order to illustrate the role of LNG, an analysis of the changes on the gas market has been carried out in countries such as the UK, Italy, France, the Netherlands, Spain, Poland, Belgium, Portugal, Greece, Lithuania and Sweden, namely, the countries which use LNG.
In 2012 natural gas consumption in the UK was $73.9 \mathrm{bcm}$ and in 2014 this figure fell to $66.7 \mathrm{bcm}$. Similarly, the LNG import dropped from $13.1 \mathrm{bcm}$ in 2012 to $10.6 \mathrm{bcm}$. The amount covered $16 \%$ of the total demand of the UK for natural gas in 2014. In 2015 an increase in the import of LNG to the UK in the amount of $12.7 \mathrm{bcm}$ could be observed. Gas was imported from Algeria - $0.37 \mathrm{bcm}$, Norway - $0.17 \mathrm{bcm}$, Trinidad and Tobago $-0.22 \mathrm{bcm}$ and from the key supplier Qatar - $12.3 \mathrm{bcm}$. The reception and regasification can be carried out in four terminals in the UK. The overall storage capacity of the British terminals in 2015 was 2.23 million cubic metres and their maximum regasification capability $53.6 \mathrm{bcm}$ per year. Among the latest tasks concerning the development of the LNG infrastructure in the UK, one seems to be worth highlighting, namely, building work aiming at adjusting the terminal on The Isle of Grain for loading gas tankers [13].

In the years 2012-2014 natural gas consumption in Italy dropped by over $17 \%$ (from 68,7 to $56.8 \mathrm{bcm}$ ). At the same time a $35 \%$ decrease in the import of LNG was recorded from $6.49 \mathrm{bcm}$ to $4.14 \mathrm{bcm}$. The amount of the LNG import to Italy could barely cover $7 \%$ of the total annual demand for natural gas. In 2015 a $30 \%$ increase in the amount of imported LNG was observed compared to 2014. Gas was imported from Qatar - 5.41 $\mathrm{bcm}$, Algeria $-0.03 \mathrm{bcm}$ and $0.05 \mathrm{bcm}$ from re-export. Regasification of LNG can be carried out in three terminals in Italy located in: Toscana, Panigaglia and Rovigo with the overall storage capacity of 0.487 million cubic metres of liquefied LNG and regasification capability equalling 15.1 billion cubic metres per year. It appears that in recent years the most important building work connected with the development of LNG infrastructure in Italy has been carried out in the terminals Toscana and Panigaglia. In the latter a decision was made in 2013 to adjust it to unloading gas tankers of over 140 thousand cubic metres (including the rebuilding of the tanks, parking trens and building the cogeneration installation). Also, in 2015 preparations for the feasibility study were started for the project of building an installation for loading tankers and tank trucks in the existing terminal.

In France natural gas consumption in the years 2012 and 2014 dropped by ca. $15 \%$ to $35.9 \mathrm{bcm}$. Similarly, LNG import declined by $36 \%$ (from 9.07 in 2012 to 5.8 $\mathrm{bcm})$. That amount covered $16 \%$ of the demand for gas at that time. In 2015 a further 5\% drop of LNG import took place (compared to 2014). The import was from (in bcm): Algeria - 4.19, Nigeria - 0.9, Norway - 0.42, Qatar - 0.24 and Peru - 0.25. Additionally, $0.46 \mathrm{bcm}$ of gas were exported from France. LNG is received in three terminals in France with the overall storage capacity of 0.84 million cubic metres and the annual regasification capability of $21.3 \mathrm{bcm}$. Among a lot of work done on the development of LNG infrastructure in France, attention should be drawn to those in Montoir de Bretagne where the installation for loading tankers was modernised (direct transmission between two tankers) and in Fos Cavou where consultations for doubling the capacity took place. 


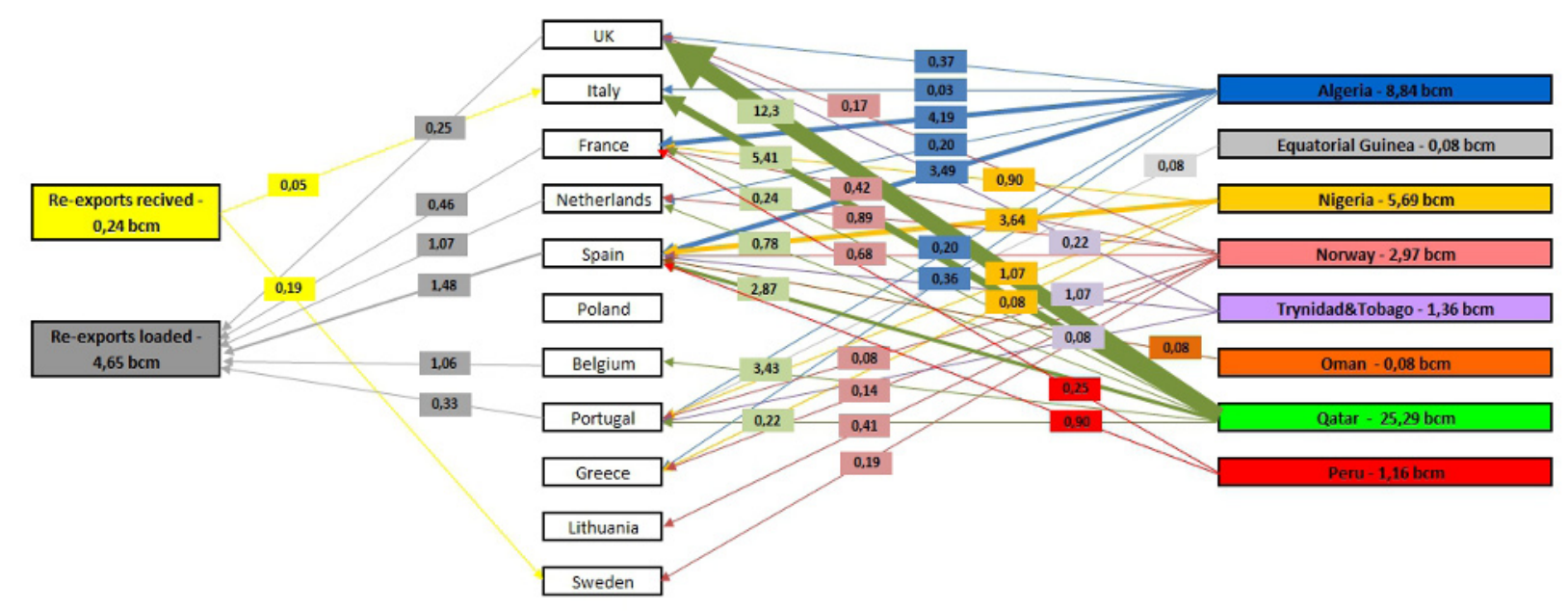

Figure 3. Directions of LNG import to the EU countries in 2015 (own study based on [13])

Also, in Fos Tonkin as of April 2015 terminal's regasification capability was reduced to 3 billion cubic metres per year. It is worth noticing that a terminal in Dunkirk is being built with the regasification capability of 13 billion cubic metres per year (expected start-up date 2016) [13].

In the Netherlands natural gas consumption in 2014 was $32.1 \mathrm{bcm}$. This amount was smaller by $11 \%$ compared to 2012. At the same time the amount of LNG import went down from 0.7 in 2012 to $0.55 \mathrm{bcm}$ in 2014 . The imported LNG covered merely $2 \%$ of the total demand for gas. In 2015 an increase in the import of LNG was recorded to $0.8 \mathrm{bcm}$ (excluding the reloaded and re-exported gas in the amount of $1.07 \mathrm{bcm}$ ). Gas was imported from (bcm): Algeria - 0.2, Norway - 0.89 and Qatar - 0.78. Reception and regasification of LNG took place in the Netherlands in the terminal in Rotterdam with the storage capacity of 0.54 million cubic metres and regasification capability of $12 \mathrm{bcm}$ per year.

Spain thanks to its geopolitical location possesses a well developed LNG infrastructure. There are seven terminals (the biggest number in the EU) with the overall regasification capability of $67.2 \mathrm{bcm}$ per year and the total storage capacity of 3.61 million cubic metres (Barcelona boasts the oldest operating LNG terminal in the EU opened in 1969). The elaborate infrastructure allows a significant share of LNG in the structure of natural gas consumption which covered $40 \%$ in 2013 and $39 \%$ in 2014 of the overall demand for gas, which to provide an example, was $26.3 \mathrm{bcm}$ in 2014 (17\% less than in 2012). It had its impact on the amount of LNG import. In 2014 a $45 \%$ fall in the import was observed compared to 2012. The situation changed in 2015 when the import rose to $11.23 \mathrm{bcm}$ and the well developed infrastructure allowed a strong diversification of supplies $(\mathrm{bcm})$ : Algeria - 3.49, Nigeria - 3.64, Norway - 0.68, Trinidad and Tobago - 1.07, the Oman - 0.08, Qatar 2.87, Peru - 0.9 and export - 1.49. The modernisation of the regasification facilities located in Spain concerned, above all, building a new tank in the terminal in Bilbao in 2014 with the storage capacity of 150 thousand cubic metres and the installation for loading tank trucks.
Attention should also be drawn to the planned projects of building regasification terminals in Gran Canaria and Tenerife [13].

In Poland natural gas consumption has maintained the level of $16 \mathrm{bcm}$ per year in the last three years. In order to realise the main objective of the energy policy of the Polish state - diversification of gas supplies, a decision was made to build the first LNG regasification terminal in Poland located in Świnoujście. Its main objective is raising Poland's energy security by gaining more independence of gas supplies from the import from the eastern directions. The terminal was officially opened in May 2016. In December 2015 it received the first supply of LNG for the installation start-up. The storage capacity of the terminal in the first stage will be 0.32 million cubic metres of liquefied LNG and the regsification capability $5 \mathrm{bcm}$ per year, which will cover $30 \%$ of the domestic demand for gas once the terminal is fully used. There is a possibility of building a third tank, which will increase the regasification capability to $7.5 \mathrm{bcm}$ per year and building an installation for reloading gas tankers and loading tank trucks. The deliveries will mostly come from Qatar within a long-term contract but also within spot contracts (first supplies in June 2016 from Norway). The operation of the terminal should have its impact on the prices of the import of natural gas to Poland [14].

In Belgium natural gas consumption in 2014 decreased by $12 \%$ compared to 2012 and the supplies in the amount of $1.21 \mathrm{bcm}$ covered $8 \%$ of the domestic demand for gas. In 2015 a 95\% increase in gas import was observed (compared to 2014) to the level of 2.32 $\mathrm{bcm}$. The imported gas came entirely from Qatar - 3.43 $\mathrm{bcm}$. Attention should be drawn to the amount of LNG export from Belgium in 2015 which was $1.06 \mathrm{bcm}$. Regasification and reloading of LNG takes place in the terminal in Zeebrugge, which has four tanks with the overall storage capacity of 0.38 million cubic metres. The annual regasification capability is $9 \mathrm{bcm}$. The important building work which is being/has been carried out within the development of LNG infrastructure in Belgium is building a second pier in Zeebrugge with the infrastructure which allows to receive small gas 
tankers up to 2 thousand cubic metres - which is to facilitate the shipment of LNG to Lysekill in Sweden. Besides, building a fifth storage tank of 0.18 million cubic metres is being planned.

Portugal, like Spain, owing to its geopolitical location in relation to the biggest deposits of natural gas requires a significant share of LNG in the structure of consumption of natural gas. The demand for it in 2014 was $3.8 \mathrm{bcm}$ (16\% less compared to 2012). The imported LNG in 2013 satisfied $45 \%$ and $33 \%$ in 2014 of the total demand for gas. In $2015 \mathrm{LNG}$ in the amount of $1.38 \mathrm{bcm}$ was imported to Portugal. The supplies were very diversified. They came from Algeria, Guinea Equatorial, Nigeria, Norway, Trinidad and Tobago and Qatar. Additionally, $0.33 \mathrm{bcm}$ of LNG were exported. The reception and regasification of $\mathrm{LNG}$ in Portugal takes place at a terminal opened in 2004 located in Sines with the storage capacity of 0.39 million cubic metres and regasification capability of $7.6 \mathrm{bcm}$ per year.

In Greece natural gas consumption in 2013 was 3.6 and in $20142.7 \mathrm{bcm}$. LNG imported to Greece in 2013 covered $16 \%$ of the demand and in $201418 \%$. In 2015 LNG import rose to $0.57 \mathrm{bcm}$ (18\% more compared to 2014) and it was imported from (in bllion cubic metres) Algeria - 0.36, Nigeria - 0.08 and Norway - 0.14. In Greece LNG regasification is carried out at a terminal in Revithoussa, opened in 2000 with the storage capacity of 0.13 million cubic metres and regasification capability of $5 \mathrm{bcm}$ per year. Within the development of the terminal, building a third tank with the storage capacity of 95 thousand cubic metres has been planned as well as building the infrastructure for loading small and medium size ships.

In Lithuania natural gas consumption in 2014 was $2.6 \mathrm{bcm}$. LNG import in 2014 was $0.14 \mathrm{bcm}$, which covered $5 \%$ of the domestic demand for gas. In 2015 it increased by over $290 \%$ to the level of $0.41 \mathrm{bcm}$ (it was the first year of the operation of the terminal under full load since its opening in 2014). LNG was entirely imported from Norway. LNG regasification takes place at the terminal in Klaipeda with the rgasification capability of 4 billion cubic metres per year. It is a socalled floating terminal (FSRU - Floating Storage Regasification Unit).

It is worth mentioning the terminals in Sweden and Malta. In Sweden a terminal in Lysekil was opened in 2014 with the storage capacity of 30 thousand cubic metres. This facility is equipped with a tank, loading docks, LNG vaporisation installation and a pipeline leading to the refinery in Preem. In Malta, however, a terminal is being built, whose main priority will be supplying gas to two gas power stations on the island. The terminal will use a floating unit as a LNG storage facility (FSRU). Regasification installations will be located on the coast.

In conclusion, it needs to be stressed that the biggest share of the LNG market in the EU in 2014 belongs to Spain and Portugal. These two countries also have the most diversified structure of supplies of gas. What is equally important is the fact that the biggest storage capacities and LNG regasification capabilities in 2015 in the EU were located in the UK and Spain.
It causes that these countries can, in all probability, increase LNG share in the structure of supplies in the future. It is also worth drawing attention to the numerous LNG projects in the EU, in the countries which already have terminals and in the countries which have started using LNG recently or which will start using it in 2016 i.e. Lithuania, Sweden, Poland and Malta.

Table 1. Characteristics of LNG regasification terminals in the EU countries (own study based on [13]).

\begin{tabular}{|c|c|c|c|}
\hline Country & Site & $\begin{array}{c}\text { Total capacity } \\
\text { liquide LNG [cm } \\
\text { liquid] }\end{array}$ & $\begin{array}{c}\text { Nominal } \\
\text { capacity } \\
\text { [bcm/y gas] }\end{array}$ \\
\hline \multirow{4}{*}{ UK } & Dragon & 320000 & 7,6 \\
\hline & Isle of Grain & 1000000 & 20,5 \\
\hline & South Hook LNG & 775000 & 21,3 \\
\hline & Teesside GasPort & 138000 & 4,2 \\
\hline \multirow{3}{*}{ Italy } & Toscana & 137500 & 3,8 \\
\hline & Panigaglia & 100000 & 3,3 \\
\hline & Rovigo & 250000 & 8,0 \\
\hline \multirow{3}{*}{ France } & Fos-Cavaou & 330000 & 8,3 \\
\hline & Fos Tonkin & 150000 & 3,0 \\
\hline & $\begin{array}{l}\text { Montoir de } \\
\text { Bretagne }\end{array}$ & 360000 & 10,0 \\
\hline Netherlands & Rotterdam & 540000 & 12,0 \\
\hline \multirow{7}{*}{ Spain } & Barcelona & 760000 & 17,1 \\
\hline & Bilbao & 450000 & 7,0 \\
\hline & Cartagena & 587000 & 11,8 \\
\hline & El Musel & 300000 & 7,1 \\
\hline & Huelva & 619500 & 11,8 \\
\hline & Mugardos & 300000 & 3,6 \\
\hline & Sagunto & 600000 & 8,8 \\
\hline Poland & Świnoujscie & 320000 & 5,0 \\
\hline Belgium & Zeebrugge & 380000 & 9,0 \\
\hline Portugal & Sines & 390000 & 7,6 \\
\hline Greece & Revithoussa & 130000 & 5,0 \\
\hline Lithuania & Klaipeda & 173000 & 4,0 \\
\hline
\end{tabular}

\section{Summary}

LNG share in relation to the overall import in the years 2008 - 2014 ranged from $13 \%$ to $25 \%$ (excluding reexport), which corresponds to the volume of supplies 41-81 bcm. Such a low level of LNG infrastructure use clearly informs about significant possibilities of increase in LNG import, which will undoubtedly be conditioned by the demand for natural gas, LNG prices (especially in relation to the import of gas through gas pipelines), accessibility of gas sent through pipeline networks as well as the political situation in the regions where the biggest deposits are. The analysis of the costs of natural gas import by the EU countries indicates that the UK had the lowest costs of gas import - ca. 35\% lower in comparison with the average cost of gas import to the EU. It can be stated beyond any doubt that a well developed transmission infrastructure enabling the UK to diversify the supplies of gas has had a considerable impact. It is worth highlighting the fact that gas supplies can be realised by both gas pipelines and 4 LNG terminals. Furthermore, the UK also stood out from other EU countries in terms of low costs of LNG import [14].

As mentioned before, the range of use the regasification potential of LNG terminals in the EU has been relatively low in recent years. It seems that the situation may change in 2016. In 2015 alone an increase in LNG import was observed in comparison with 2014 
due to the decrease in the prices of LNG. In the period between May 2013 and January 2016 the prices of LNG in the EU went down by ca. $50 \%$ on average [16]. It has been mainly caused by the falling prices of oil in recent years. Current situation on the LNG market and the low prices will probably support a rising trend of LNG supplies within spot contracts. The rising role of LNG in supplying the EU can also be connected with the start of LNG export from the USA to Europe (first supply from the Sabine Pass terminal in Louisiana reached Portugal in April 2016). One must not forget about the projects being carried out which will increase the world supply of LNG in the near future, especially about Australia's plans in this respect [17] [18].

Hopes for the increase in the significance of LNG in the EU are also connected with the use of this fuel in transport, particularly sea transport, after the introduction of rigorous regulations limiting the content of sulphur in fuels used by ships in SECA (Sulphur Emission Control Areas) regions [19].

\section{References}

1. M. Gałczyński, M. Ruszel, P. Turowski, R. Zajdler, A. Zawisza - Globalny rynek $L N G$, Wydawnictwo Rambler, Warszawa 2015

2. Rychlicki, J. Siemek, Polityka Energetyczna Energy Policy Journal, 11, 1 (2008)

3. M. Ruszel, Polityka i Społeczeństwo, 4, 12 (2014), Uniwersytet Rzeszowski

4. K. Ficoń. W. Sokołowski, Logistyka, 5 (2012)

5. LNG SNAPSHOT (Analysis) http://lngsnapshot.com

6. M. Malec, J. Kamiński, P. Kaszyński, Polityka Energetyczna - Energy Policy Journal, 19, 1 (2016)

7. L. Gawlik, A. Szurlej, A. Wyrwa, ENERGY, 92 (2015)

8. Eurogas Statistical Report, http://www.eurogas.org (2007-2015)

9. BP Statistical Review of World Energy, https://www.bp.com/ (2015)

10. A. Szurlej, J. Kamiński, P. Janusz, K. Iwicki, T. Mirowski, Rynek Energii, 6, 115 (2014).

11. J. Siemek, S. Nagy, Archives of Mining Sciences Archiwum Górnictwa, 57, 2 (2012)

12. M. Kaliski, P. Janusz, A. Szurlej, Gaz, Woda i Technika Sanitarna, 83, 7-8 (2009)

13. The LNG Industry in 2013-2016, Groupe International des Importateurs de Gaz Naturel Liquéfié, http://www.giignl.org

14. A. Szurlej, M. Ruszel, T. Olkuski, Rynek Energii, 5 (2015)

15. R. Biały, P. Janusz, M. Łoś, A. Szurlej: Zeszyty Naukowe Instytutu Gospodarki Surowcami Mineralnymi i Energia PAN, 87 (2014)

16. The Federal Energy Regulatory Commission (FERC): www.ferc.gov.

17. M. Kaliski, R. Wojciechowski, A. Szurlej, Polityka Energetyczna-Energy Policy Journal, 14, 4 (2013)

18. P. Janusz, M. Kaliski, A. Szurlej, Gospodarka Surowcami Mineralnymi/Mineral Resources Management, 31, 3 (2015)

19. M. Krupa, M. Moskalewicz, A. P. Sikora, A. Szurlej, Przemyst Chemiczny, 94, 12 (2015) 